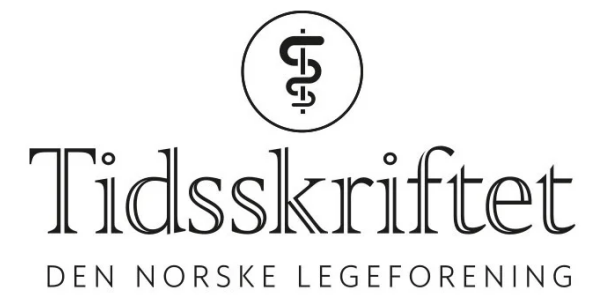

\title{
Kan periodisk faste øke sunn livslengde?
}

FRA ANDRE TIDSSKRIFTER

HAAKON B. BENESTAD

Universitetet i Oslo

Fors $\varnothing \mathrm{k}$ med bananfluer viser at $\emptyset \mathrm{kt}$ autofagi ved periodisk faste kan forlenge livet og redusere aldersorgansvikten. 


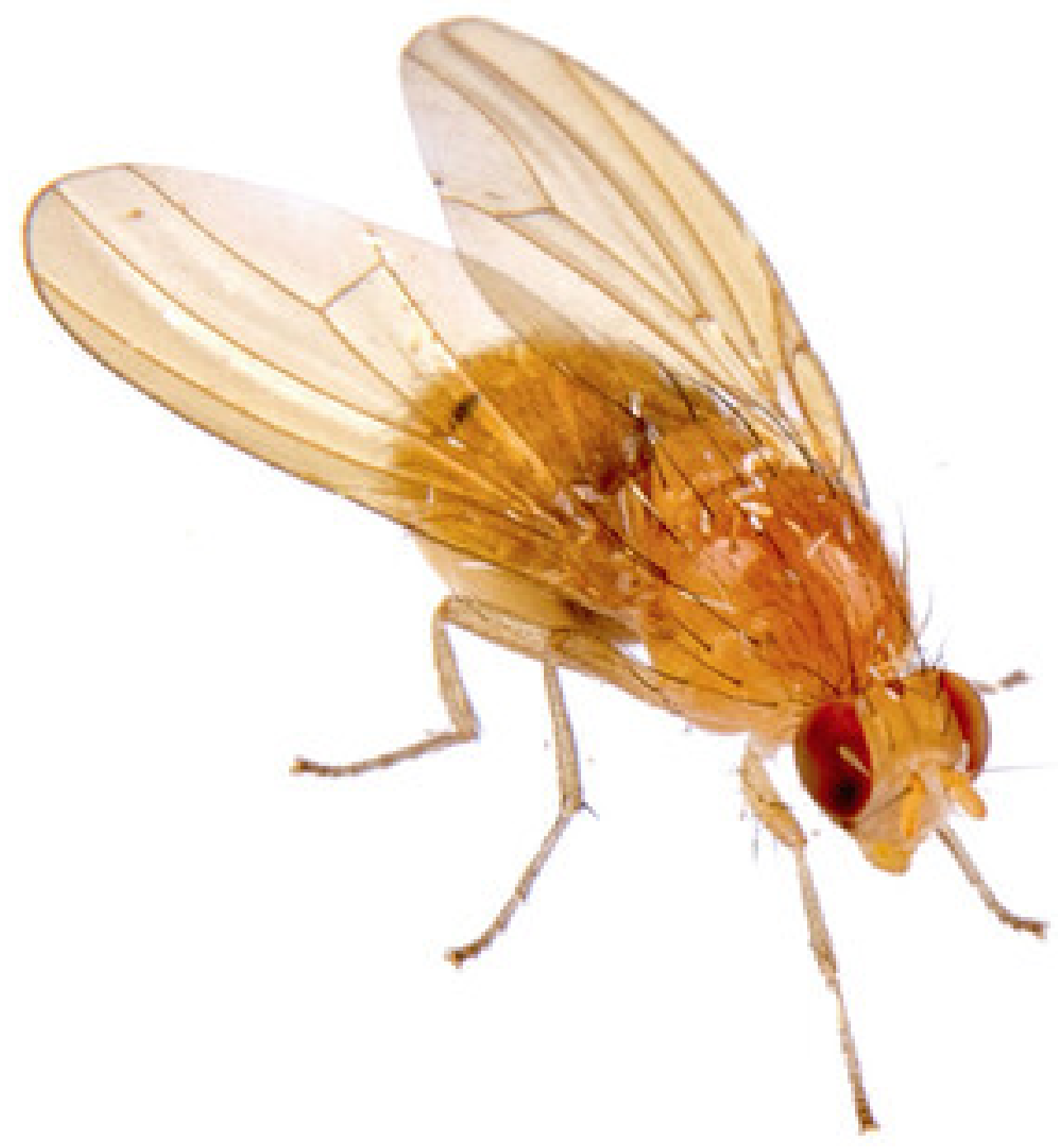

Illustrasjon: NERYX/iStock

Periodisk faste uten redusert fødeinntak over tid har vært sett på som en potensiell antialdringsmekanisme i mange organismer, bl.a. bananfluer, mus og mennesker. Effekten ser ut til å bero på fysiologiske funksjoner med døgnsvingninger, såkalt diurnal rytme, men de molekylære mekanismene er ikke klarlagt.

Bananfluer har en døgnrytme med en periode på 24 timer, omtrent som mennesker. Autofagi er en prosess der utbrukte cellebestanddeler brytes ned til gjenbruk. Prosessen foregår mest intenst om natten. I en ny studie med bananfluer ble denne autofagien forsterket av fasteperioder på 20 timer når fasteperiodene strakte seg over hele natten, og med spiseperioder på 28 timer mellom fasteperiodene (11). Kun nattefaste, og ikke dagfaste, førte til den ønskete forlengelsen av livslengden. Livslengden var avhengig av alder og $ø$ kte i snitt $18 \%$ for hunnfluer og $12 \%$ for hannfluer. Transkripsjonen av døgnrytmeregulerende gener var sterkest om natten og økte ytterligere under faste. Disse genene aktiverer transkripsjonen av hundrevis av andre gener, bl.a. de som regulerer autofagi, som også ble $\emptyset \mathrm{kt}$ nattestid av fasten. Med $ø \mathrm{kt}$ livslengde $ø$ kte ikke de vanlige aldersdegenerative tegn i muskler og tarm - motsatt skjebnen til Tithonos, som i gresk mytologi ble skjenket evig liv, men med tiltakende aldringssvinn.

Ved å slå av gener som styrer den diurnale rytmen, viste studien at normal døgnrytme er påkrevet og tilstrekkelig for den livsforlengende virkningen av periodisk faste. Også hos mennesket skal periodisk faste angivelig ha gunstige effekter selv ved opprettholdt 
kaloriinntak, slik som senket blodtrykk, bedret glukosemetabolisme og $\emptyset \mathrm{kt}$ fysisk utholdenhet. Hvor stor del av voksenlivet et fasteregime bør vare, må utforskes nærmere, skriver forfatterne.

- Man har lenge visst at kalorirestriksjon kan forlenge livet, sier Anne Simonsen, som er professor ved Institutt for medisinske basalfag ved Universitetet i Oslo.

- Denne studien er veldig spennende fordi den antyder at vi kan redusere forekomsten av aldersrelaterte sykdommer og forlenge livet ved å endre når vi spiser uten å redusere totalt kaloriinntak. Det er interessant at den livsforlengende effekten av 20 timers faste annenhver natt var best blant «middelaldrende» bananfluer. Bananfluer er overraskende like oss mennesker, så det er all grunn til å tro at et tilsvarende fasteregime vil ha gunstig effekt på vår helse og vår aldringsprosess, sier Simonsen, som understreker at ytterligere studier er påkrevet for å dokumentere samme effekt hos mennesker. Hun mener at det også vil være interessant å se om et slikt fasteregime kan benyttes for å behandle ulike aldersrelaterte sykdommer, eventuelt sammen med legemidler.

\section{LITTERATUR}

1. Ulgherait M, Midoun AM, Park SJ et al. Circadian autophagy drives iTRF-mediated longevity. Nature 2021; 598:353-8. [PubMed][CrossRef]

Publisert: 13. desember 2021. Tidsskr Nor Legeforen. DOI: 10.4045/tidsskr.21.0765

(C) Tidsskrift for Den norske legeforening 2023. Lastet ned fra tidsskriftet.no 26. april 2023. 